\title{
John Gilderbloom's Thought-Provoking Strategies About Regeneration and the Language of Planning
}

\author{
Jana Schwartz \\ MCRP student, Cal Poly San Luis Obispo.
}

Planning is a 'jargon-y' field with terminology that oftens distract from the purpose of a project or idea. During a luncheon seminar at Cal Poly, Dr. John I. Gilderbloom, a professor at the University of Louisville, Kentucky, addressed this challenge through his own work, case studies and personal antidotes. He discussed the intricacies of planning and the role played by language in the implementation of projects and community understanding.

I: n February 2015, Dr. John I. Gilderbloom presented the talk "The 10 Commandments of Urban Regeneration" at Cal Poly sponsored by the Resilient Communities Research Institute. During his visit, he also presented his ideas to CRP's students and faculty during a brown-bag session. A professor in the Department of Urban and Public Affairs at the University of Louisville and director at the Center for Sustainable Urban Neighborhoods, Dr. Gilderbloom is a notable planning professional and academic considered one of the "top 100 urban thinkers in the world." He is an international consultant on creating livable cities and neighborhoods, and owns a real estate company that renovates historic housing. A Marxist-like scholar who uses divergent thinking to expand the way planners and students envision the future of our communities, he has published widely on rental housing, poverty, health, community development, and urban policy. Dr. Gilderbloom explores thought-provoking planning question from sometimes unusual or even revolutionary perspectives.

One of Dr. Gilderbloom's connections to Cal Poly comes through City and Regional Planning professor, Dr. William Riggs who worked with him during his Master's at the University of Louisville. The two teamed us again more recently to produce a highly successful article on the conversion of one-way streets to two-way streets (Riggs \& Gilderbloom, 2015). This work was featured in Dr. Gilderbloom's talk, along with other provocative topics such as the benefits of gentrifying neighborhoods with the goal of creating healthy, safe, prosperous, sustainable, and just neighborhoods.

The resonance of this topic of the pros and cons of gentrification and it's relationship to urban planning is an important one and was the key concept that many in attendance took away. There was a key unspoken question throughout the entire talk. It screamed: How do we balance regeneration and economic development with justice? How do we achieve the benefits of neighborhood improvement without gentrification and displacement? While Dr. Gilderbloom talked about his work on the benefits of walkable communities or creating job growth,

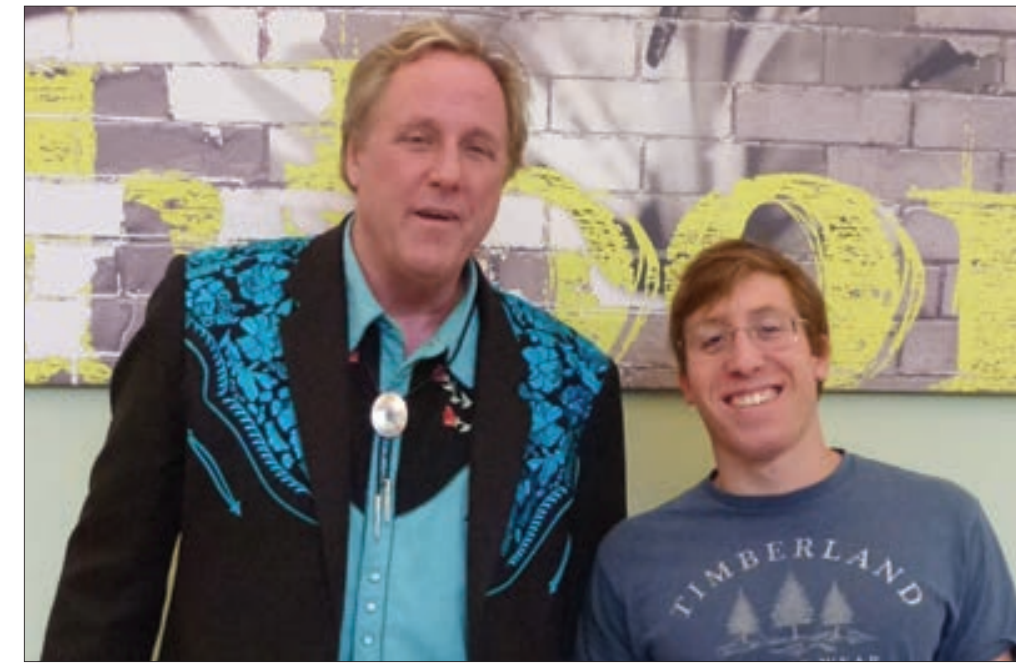

Dr. Gilderbloom with BSCRP student Rob Etters, after

his presentation. (Photo: William Siembieda)

the facts and interlaced ideas between gentrification and regeneration resulted in further significant group dialogue long after the talk.

Dr. Gilderbloom provided factoids about all types of benefits provided by gentrification. These included affordable housing, displacement, diversity of amenities, and project appropriateness-based on environmental and demographic make-up. He offered suggestions on how to supply these opportunities to all communities, primarily through urban regeneration and infill. Dr. Gilderbloom provided several case studies that illustrated the impact his dialogue was describing. Dr. Gilderbloom comes from a diverse and arguably depressed area of Louisville that presents ample regeneration, or gentrifying, opportunities. In one case, a development project near the University of Louisville, which houses 500 people, has introduced 12 new stores and businesses and approximately 75 jobs. Of these jobs, $82 \%$ of these jobs are going to people without high 
school diplomas, and half of these jobs are going to minorities, which is important since the highest unemployment rate is for people without high school diplomas.

Of these newly introduced opportunities, Dr. Gilderbloom explained how this type of neighborhood investment "allows for 17 jobs to be created for every \$1 million in investment in urban regeneration, often through historic preservation." Using freeway construction as a comparison, Gilderbloom stated that "only 5 jobs are created" per \$1 million, with large machines overtaking many of these jobs. In his mind the difference between the two relies heavily on community investment and local spending, a cycle of economic support that generates jobs and sustainable growth patterns. Not only are workers being paid to reconstruct these new, usable neighborhoods, but these workers go to the local businesses to get materials, providing additional jobs for the community. Similarly, due to the growing success of the local economy because of these investments, stores will move to that area helping create other employment offerings. In turn, housing development, renovation, and renewal projects regenerate structural, economic, and equitable growth opportunities.

Based on this pattern of regeneration described in his talk, Dr. Gilderbloom posed gentrification as an economic driver versus a community and societal villain - a perspective rarely seen in the media these days. Gentrification often gets this evil name because of its synonymous use with "displacement." However, in 2010, University of Colorado-Boulder economist Terra McKinnish, along with Randall Walsh and Kirk White, examined gentrification across the nation as a whole over the course of the 1990s. McKinnish and her colleagues found that gentrification created neighborhoods that were attractive to minority households, particularly households with children or elderly homeowners. They found no evidence of displacement or harm. While most of the income gains in these neighborhoods went to white college graduates under the age of 40 (the archetypical gentrifiers), black high school graduates also saw their incomes rise. They also were more likely to stay put. In short, black households with high school degrees seemed to benefit from gentrification.

This relates to Gilderbloom' s talk in that his experience is largely comprised of work done in poor, black neighborhoods. One thing he talked about was frequently encountering people people complaining about gentrification but at the same time want to go in and "fix a black neighborhood." He went on to explain that he was once involved with a book project:

"...but they didn't like the chapter on improving black neighborhoods. They said that if you improve black neighborhoods with bike lanes and mixed use, it will force blacks out. And I said, I think that's racist? We should have the same sort of amenities and equity in all neighborhoods, like in Portland. There are programs like co-op housing and rent control that are supportive of these neighborhoods and preserving the integrity of the community."
In this proactive thought Gilderbloom illustrated a key issue planners face and what I believed was the key take away from the talk - terminology. In city planning (and perhaps government in general) there tends to be a common tongue; something that I have heard Dr. Riggs call ' planner-speak.' We tend to use certain phrases or acronyms that carry a certain connotation, however what Dr. Gilderbloom illustrated was that they do not have to carry this meaning. There is no reason why gentrification cannot mean a phenomenon with both the potential for positive and negative outcomes. And perhaps this should be our goal as planners. Perhaps we should try to reduce the negative and increase the positive. This thought was at the core of what Gilderbloom was talking about, and is an important take-away for practice.

Put succinctly, Dr. Gilderbloom may have a contrarian perspective, but his research and ideas require further discussion. In my case, his lecture left me feeling inquisitive and interested in his refreshing lack of political correctness. His perspective is optimistic and wide, and provides an opportunity to think critically and take part in discussions that evaluate the lessexplored perspectives of planning - with a key lesson to ' dejargonize' the planning field. So when you begin to reevaluate how traditional planning ideas might be interpreted differently or find yourself using common planning terms without considering the implications or alternative meanings, think again. There are other perspectives out there and they may have merit -Gilderbloom or not.

\section{References}

Riggs, W., \& Gilderbloom, J. 2015. Two-Way Street Conversion Evidence of Increased Livability in Louisville. In Journal of Planning Education and Research, http://doi.org/10.1177/0739456X15593147

Planetizen. 2014. Top 100 Urban Thinkers. http://www.planetizen.com/topthinkers. Accessed 30 November 2015.

Buntin, John. 2015. Gentrification Is a Myth. Slate. http://www. slate.com/articles/news_and_politics/politics/2015/01/ the_gentrification_myth_it_s_rare_and_not_as_bad_for_ the_poor_as_people.html. Accessed 30 November 2015. 